\title{
From rhetoric to action, a constitutional analysis of populism
}

\author{
Théo Fournier*
}

(Received 31 December 2018; accepted 31 January 2019)

\begin{abstract}
The article considers populism not as common ideology but as a common strategy for implementing various distinct ideologies. Constitutional democracy and populist strategy are inherently connected. Populist strategies develop a specific rhetoric which takes root in the features of constitutional democracy. The populist rhetoric manipulates the rule-of-law and the majoritarian pillars of constitutional democracy by convincing a fictional majority that constitutional democracy gives rise to a tyranny of minorities. Populism in action represents the second facet of the populist strategy. It corresponds to a specific constitutional strategy of legal and constitutional reforms aiming at disrupting constitutional democracy. After exposing my theoretical assumption, I move to a comparative study of two countries, France and Hungary, selected according to the most different cases approach. I analyze first how Viktor Orban based his constitutional strategy on a progressive deconstruction of the post-communist legacy. I study then how Marine le Pen's strategy consisted of a comprehensive reform of the French semi-presidential system via referendum. I finally conclude by recalling the essential role academics have to play in the fight against populism. My last point is a provocation, what if calling populism by its real diversity (fascism, racism and antisemitism) was the most efficient way to fight them?
\end{abstract}

Keywords: Marine Le Pen; instrumentalism; illiberal constitutionalism

\section{A. Introduction}

Over the last two years, the study of populism has been flourishing. Since the first draft of this Article was completed in March 2017, the rise of populism has led to the publications of dozens of books and articles and to the organization of as many workshops in leading political and legal circles. The speed at which these changes have taken place makes it difficult for a lone academic to keep up. For someone interested in populism, however, one can admit only that the chase is worth it - the emergence of populism has been followed by a magnificent activism on part of the academic community. The present author did not escape this frenetic activism. The first draft of this Article was a blog post aimed at denouncing Marine le Pen's constitutional program, published a few months before the 2017 French election. Nine months later, that blog post turned into a more substantial piece and was presented in November 2017 during a colloquium at the European University Institute. The latest version of this Article came out in December 2018, almost two years after the first lines were put on paper.

Which methodology is the best tailored to analyze populism? When I started this project, the tendency was to focus on populism as a global phenomenon. The same way we had waves of

\footnotetext{
*Théo Fournier is a Ph.D. researcher in the Law Department at the European University Institute of Florence, Italy. The
} author would like to thank Lia Brazil, Oliver Garner, Adam Humphreys, and Lene Korseberg for their help. 
democratization, we were now facing waves of populism. Populism would be a global movement with a specific ideology transplantable from one State to another-with the help of a chain of solidarity between the populist leaders. I did fall for the temptation of studying populism as a global phenomenon. I compared populism to a parasite slowly spreading in the constitutional world. This medical image - or the idea of waves of populism-was arguably accurate to give a first overview of the populist phenomenon. Populism did spread worldwide between February 2017 and December 2018. In this period, the signs of remission were scarce. Populism lost some influence both in Germany-where the Greens, and no longer AFD, seemed to be the new trendy political force-and in France-after the victory of Emmanuel Macron at the 2017 presidential election. In other countries, the disease has taken roots and is unlikely to be cured. In the United States, commentators gave Trump a few months before his inevitable impeachmenthe is now in a good position to win the 2020 election. In Hungary, the European parliament stood up against Viktor Orban's plan to close the Central European University-but the European People's Party recently renewed its support in the Hungarian prime minister. In the Philippines, Austria, and the Czech Republic, populist leaders are still in power-but they are no longer a trendy topic for the media.

In other political contexts, populism continued its contamination. In Brazil, populism gained power at the expense of Lula's Socialist Party. In Europe, the most dramatic example is Italy, with the unnatural alliance between La Lega and Il Movimento 5 Stelle after the 2018 elections. Yet analyzing populism through the idea of a common—and global-ideology is, in my opinion, not the best methodological approach. When Donald Trump yells "America First," he rejects any sort of solidarity with other countries - even with Brazil, despite the election of Bolsonaro. When Viktor Orban refuses any immigrant access to Hungarian territory, he is in clear opposition with his "dear friend" Matteo Salvini, who advocates for a greater European solidarity in the repartition of migrants. ${ }^{1}$

This Article considers populism not as common ideology, but as a common strategy for implementing various distinct ideologies. To identify the common strategy, I followed the "most different cases" approach. ${ }^{2}$ The aforementioned countries differ on everything-history, institutions, division of powers - except on the fact of being constitutional democracies. My stand is that constitutional democracy and populist strategy are inherently connected. The evolution of constitutional democracy and the implementation of its special features give rise to a specific rhetoric in the same way, according to Aristotle, democracy can be corrupted into demagogy. My demonstration relies first on a theoretical presentation of the relationship between populism and constitutional democracies. In part B, I suggest a division of populism into a strategy of rhetoric and a strategy for action. Populist strategies first develop a specific rhetoric which takes root in the features of constitutional democracy. The populist rhetoric manipulates the rule of law and the majoritarian pillars of constitutional democracy by convincing a fictional majority that constitutional democracy gives rise to a tyranny of minorities. Populism in action represents the second facet of the populist strategy. It corresponds to a specific constitutional strategy of legal and constitutional reforms aiming at disrupting constitutional democracy.

In Part C, I apply my theoretical construction to the case studies of Hungary. Hungary has almost become a prototypical choice. It is the European country in which populism has been in power for the longest period-more than eight years. Since 2010, Viktor Orban methodically destroyed - and is still destroying - the legacy of the post-communist democratic transition. He did so following a precise strategy of constitutional amendment coupled with a specific populist

\footnotetext{
${ }^{1}$ For a different approach on transnational forms of populism (focused on left-wing populism), see Paul Blokker, in this issue.

${ }^{2}$ Ran Hirschl, Comparative matters: The Renaissance of Comparative Constitutional Law 224-82 (1st ed. 2014) (discussing relevant material related to this approach in Chapter 6, titled "Case Selection and Research Design in Comparative Constitutional Studies").
} 
rhetoric. The case of Hungary is a good illustration of what populism in action looks like. In Part D, I apply my theoretical construction to the case studies of France. The case of France is a less typical choice, but remains topical for two reasons. First, one cannot deny the success of Marine le Pen's populist rhetoric. Marine le Pen's Front National (FN) ${ }^{3}$ had oscillated between the largest and the second largest party for almost a decade. Marine le Pen claimed to be the European leader of the anti-European political movements. Second, France is considered to be a consolidated democracy. French institutions should be solid enough to resist populist assaults thanks to a well-spread constitutional culture. I argue the contrary-despite its constitutional history and the result of the 2017 presidential elections, France is not equipped with the adequate constitutional tools to efficiently counter populism in action.

\section{B. The equilibrium of constitutional democracies against the populist strategy}

The relation between populism and constitutional democracy is comparable to a process of parasitism in which constitutional democracy would be the host and populism would be the parasite. With the parasite analogy, populism is not an external phenomenon, but rather is grounded in constitutional democracy. Populism appears because of the specific features of constitutional democracy and prospers alongside the growth of constitutional democracy. The development of constitutional democracy gives substance to populism for the construction of a specific strategy. Populist strategy has the first objective to anchor populism in the constitutional system thanks to a specific rhetoric. It has the second objective to destroy the same constitutional system thanks to a set of constitutional reforms.

\section{Synthesis to dichotomy, the populist rhetoric}

Constitutional democracy is a synthesis between the rule of the majority and the rule of law. ${ }^{4}$ The rule of the majority proceeds from a procedural vision of democracy. Constitutional democracy elaborates an institutional framework to secure the expression of the majority. This institutional framework consists of free and fair elections to ensure that the expression of the votes actually represents the majority of the citizenry, as well as instruments of representation such as a Parliament used to transform the outcome of the vote into specific policies. The majority in a constitutional democracy can decide the political orientations of the State for the duration of the mandate. ${ }^{5}$ A constitutional democracy does not stop for the rule of the majority. It is composed of an equally as important pillar, the rule of law pillar. Choices of the majority are not unrestricted. Elections are only one of the many different facets of a constitutional democracy, and the outcome of the elections-despite its majoritarian characteristics—can by no means oppress the minority. In a constitutional democracy, the rule of law pillar limits the choices of the majority and protects non-majoritarian individuals from the consequences of not belonging to the majority. ${ }^{6}$ The constitution does not only organize majoritarian institutions ${ }^{7}$-its rule of

\footnotetext{
${ }^{3}$ In June 2018, the Rassemblement National became the official new name of the Front National. Here, changing the name is also part of the populist strategy. This new label is an attempt to disguise the ideology of the Le Pen family (based on rampant antisemitism and racism). As the constitutional program was adopted under its original name, I will use Front National in this Article.

${ }^{4}$ Walter F. Murphy, Constitutional Democracy: Creating and Maintaining a Just Political Order 5-12 (2007).

${ }^{5}$ Joseph A. SCHUMPETER, CAPITALisM, SOCIALISM AND DEMOCRACY 241 (Routledge Classics 2010) (1942) (stating a political regime is democratic in the presence of "institutional arrangement for arriving at political decisions in which individuals acquire the power to decide by means of a competitive struggle for the people's vote").

${ }^{6}$ David Held, Models of Democracy 56-95 (3rd ed. 2006).

${ }^{7}$ See R. Carré de Malberg, Contribution à la Théorie Générale de l'Etat: Spécialement d’Après les Données Fournies PAR LE Droit Constitutionnel FrançAis (1920) (explaining that institutions representing the popular sovereignty, such as a representative parliament, are limited only by the elections), at 232-234.
} 
law pillar avoids a coercion of the minority by the majority. ${ }^{8}$ The rule of law pillar usually includes a bill of rights and a specific method for constitutional review-a constitutional court being the ideal-type. ${ }^{9}$

The balance between majority rule and rule of law makes constitutional democracy a nonnatural ecosystem. How natural is it to claim to be a democratic regime while, at the same time, constraining the choice of the majority? How does one justify the final and binding authority of a constitutional court - a non-elected body-against the willingness of the Parliament-the national representation? Arguing that the constitution legitimizes this unnatural balance is even more unnatural. How does one justify that rules written decades ago-by a generation often no longer alive-can constrain a contemporary majority? If the principle of a constitution is accepted, why then restrain its amendments to a supra-majority? Constitutional democracy is an unnatural and consequently fragile ecosystem. Populist strategy takes advantages of this fragility. It develops a rhetoric which is tailored to exploit the weaknesses of constitutional democracies. ${ }^{10}$

Populist rhetoric is the use of political arguments aimed to convince a fictional majority that a constitutional democracy gives rise to a tyranny of minorities. A rhetoric is a "language designed to have a persuasive or impressive effect, but which is often regarded as lacking in sincerity or meaningful content." 11 Populist strategy uses a rhetoric and not a discourse. A discourse is neutrally charged, whereas a rhetoric has a specific objective. Rhetoric implies a fiction-a manipulation of reality - which is exactly what populist rhetoric is about.

Populist rhetoric manipulates the rule of the majority pillar in two ways. Populist rhetoric transforms the heterogeneous majority of constitutional democracy into a unified one. With populist rhetoric, the majority cannot be divided nor differentiated. Such a rhetoric is fictional because it disregards the constitutional democracy's concept of majority. Majority in a constitutional democracy is a matter of political choice. If there is the expression of a majoritarian preference through a vote, this expression is nothing other than the aggregate of minority expectations. Constitutional democracy does not create a single popular block. The people, the Nation, or the citizens in a constitutional democracy are never homogenous categories-even if citizens can have similar political choices. Pluralism of the majority is essential to create a political dialogue and a political consensus among the population. ${ }^{12}$ Populist rhetoric refuses any pluralistic vision of the majority. Populist leaders claim to be the spokesperson of the Nation which, because of its unity, can have only one representative.

The unified majority of the populist rhetoric is also an uncompromised one. Populist rhetoric defines democracy numerically. A majority of the votes, even if not absolute, must be the expression of a non-negotiable political truth. If the populists win the elections, then it is the people in its entirety who expressed its willingness of having the populists in power. With the populist rhetoric, a victory of populism erases any dissident vote and any distinguishing features among the citizenry. The uncompromised majority leaves no room for minorities who are considered as the "non-people." Populist rhetoric remains the same in case of victory for the opponent. If populists lose an election, then it is the Nation-an uncompromised majority of the citizenry-as a whole who has lost. Populist rhetoric denies any legitimacy of the winning party to represent the Nation because the candidate was elected thanks to a strategic cooperation of minorities. At such a point, anything but the Nation is in power.

\footnotetext{
${ }^{8}$ John Dewey, The Early Works: 1882-1898, at 233 (Jo Ann Boydston ed. 1972).

${ }^{9}$ Alec Stone Sweet, Constitutional Courts, in Oxford HANDBook of Comparative Constitutional Law, 817 (Michel Rosenfeld \& András Sajó eds., 2012); see also Tom Ginsburg \& Mila Versteeg, Why Do Countries Adopt Constitutional Review?, 30 J.L. ECON. \& ORG. 587 (2014) (explaining that there is an empirical tendency to concentrate constitutional review into constitutional courts).

${ }^{10} \mathrm{Kim}$ Lane Scheppele, in this issue, explains how populists understand the weaknesses of constitutional democracies. She focuses specifically on the criticism of liberalism.

${ }^{11}$ Rhetoric, OXFORDDICTIONARIES.COM, https://en.oxforddictionaries.com/definition/rhetoric (last visited Dec. 10, 2018).

${ }^{12}$ Dewey, supra note 7 , at 234.
} 
Populist rhetoric couples the manipulation of the majority pillar with the manipulation of the rule of law pillar. Populist rhetoric transforms the fragile equilibrium of constitutional democracy into a balance of power. The majority and the rule of law are no longer presented side-by-side, but in opposition. With populist rhetoric, the majority-meaning the unified and uncompromised majority-should not compromise with any rule, especially when the guardians of these rules are non-elected institutions. Populist rhetoric creates a political myth and reverses the logic of constitutional democracy. Constitutional democracy has been thought of as a protection of minorities from a tyranny of the majority. Yet, according to populist rhetoric, constitutional democracy should protect the majority from the tyranny of minorities. Protection against the tyranny of minorities stands for a superiority of the majority pillar over the rule of law pillarit disrupts the original equilibrium of constitutional democracy. The hypothetical victory of a populist party does not change the rhetoric on the rule of law, which is accommodated only with the unified and uncompromised majority. As the majority cannot be compromised-and as it represents the Nation as a whole-rule of law is futile. What is the point of constraining the will of the majority if the same majority is always right?

\section{Populist in action and political reality}

There are two common assumptions when confronting populist strategy and political reality-the theory of the glass ceiling and the theory of the consolidated democracy. The theory of the glass ceiling considers that populist parties cannot win general elections because they cannot go beyond a specific threshold of votes. This assumption is denying any effect of the rhetoric on the electoral outcome. Populism remains a political rhetoric and populist parties are and will remain forces of opposition. Populist political parties cause a stir, occupy media coverage, and manage to influence political debates, but without any concrete electoral results. Election campaigns do put more spotlight on them, but without changing the outcome of the elections. The glass ceiling theory seems verifiable in some constitutional democracies: France, where Marine le Pen did not win the 2017 presidential elections; Germany, where the Alternative für Deutschland (AFD) is far from having a parliamentary majority; or the United-Kingdom, where the United-Kingdom Independence Party (UKIP) struggles to have a parliamentary representation. In these three countries, populist rhetoric failed to convince the population to give the keys of power to a populist party.

Yet the theory of the glass ceiling is too fragile to be considered a satisfying shelter against populist assaults. To the exceptions of France, Germany, and the United-Kingdom, one could present Poland, Hungary, Brazil, the USA, and the Philippines. To the situations in France, Germany, and the United-Kingdom, one could also temper the lack of influence of populist strategies. We unfortunately live in a time in which populist parties do not need to be in power to influence the everyday politics. The most salient example is the Brexit referendum organized by David Cameron, pressured by the growing influence of the UKIP. ${ }^{13}$ In Germany, the main candidates for the recent campaign of the Christian-Democrats that promised their electorate a shift towards the right to counter the rise of the AFD. As a reaction to the 2016 terrorist attacks, the then-socialist French government wanted to amend the Constitution in order to constitutionalize the state of emergency. They also proposed to incorporate into the Constitution a disposition central to FN's political program - the deprivation of nationality for French-born dual nationals guilty of the most serious crimes. ${ }^{14}$ Leaving Germany aside, the political weight of the populist

\footnotetext{
${ }^{13}$ BreXit: Sociological Responses 13 (William OuthWAite ed. 2017)

The elected presence of the party enabled UKIP [...] forced both Major and later Cameron into referendum promises they would surely rather have avoided if they possibly could have done so.

${ }^{14}$ Interviewed at the margin of the debates, Florian Philipot-the then-Front National's then-second in commanddeclared that this measure had been advocated by Marine le Pen directly to François Hollande just after the November attacks. See Florian Philippot sur I>Télé, FN - FronT NATIONAL, http://www.frontnational.com/videos/florian-philippot-sur-itele-90/ (last visited Nov. 10, 2017).
} 
parties in the cases of France and the UK was insignificant. UKIP occupied one seat in the House of Commons and FN only two in the National Assembly. It was as forces of opposition and not as forces of government that populist parties imposed their political agenda.

The next assumption when confronting populist strategy and political reality is the theory of the consolidated democracy. Tenants of this theory do not exclude the victory of a populist party at general elections. They even admit that the populist rhetoric can help to surpass the electoral glass ceiling. Yet tenants of the theory of the consolidated democracy deny that the populist strategy can transform the equilibrium of constitutional democracy. Once in power, populist parties would be confronted with a long-held tradition of constitutional democracy. This theory distinguishes between the democratic institutions and the political actors-between winning an election and the act of governing. In a consolidated democracy, the institutions are strong enough to resist the assault of populist rhetoric. The institutions are democratic, so there is always a possibility for the anti-democratic parties to win the elections. But these same parties will be forced to accept the institutional reality they evolve in and will have to eventually abandon their anti-democratic reforms.

For constitutional scholars and political scientists, the theory of the consolidated democracy is reassuring. It illustrates a logic of linear evolution-from the constitutional transition to the constitution-making process - and the consolidation of the constitutional and democratic rules. ${ }^{15}$ The theory of consolidated democracy is undoubtedly optimistic. It creates an automaticity between the duration of the democracy and the acceptance of the constitutional rules by the citizenry. Constitutional democracies, thanks to their mechanisms, spread a constitutional culture among the citizenry and the institutions. This theory creates a virtuous circle of legitimacy-and legitimation - between the Constitution, the citizenry, and the institutions. ${ }^{16}$ When confronting a populist party in power, the same circle becomes a shield against their non-democratic assaults.

The theory of consolidated democracy remains - as every theory does - a simplification. First, the current state of research in constitutional law does not confirm-though nor does it denyany assumptions regarding constitutional culture in constitutional democracies. The tendency would be the contrary-a non-automaticity between the duration of a constitutional democracy and a spread of constitutional culture. If there was a spread of constitutional culture among the citizenry then there should not be such a strong political support of populist parties. Second, this theory gives too much importance to the normative considerations and the institutional design of check and balances. Risks of anti-democratic backlashes can be anticipated during the constitution-drafting process. A thoughtful and well-tuned institutional design could prevent non-democratic practices even with a populist party is in power. To take the medical analogy used before, checks and balances, veto players, and institutional equilibrium would prevent the contamination and limit populism to one institution. In a presidential regime, the strict separation of power can isolate populism to the presidency. In a parliamentary regime, the constitutional court would always be the guardian of the constitution in front of a populist government and parliament. Institutional tricks such as checks and balances or veto players do have a role to play in securing the equilibrium of constitutional democracy. But it would be foolish to think that a constitutional dynamism - the evolution of a constitution through amendment and practice-will forever follow the plans of the drafters.

The theory of consolidated democracies is appealing, but it does deny political reality. The current political reality is that the populist strategy is not limited to a political rhetoric. It is

\footnotetext{
${ }^{15}$ Juan J. Linz \& Alfred C. Stepan, Problems of Democratic Transition and Consolidation: Southern Europe, South America, And Post-Communist Europe (1996); see also Philippe C. Schmitter, From Transitology to Consolidology, in Democratisation in the 21st Century: Reviving Transitology 167 (Mohammad-Mahmoud Ould Mohamedou \& Timothy D. Sisk eds., 2016); see also RoBerT A. DAhL, Polyarchy: PARTICIPATION AND OpPosition (1971) (explaining that this hypothesis is at the core of the consolidation theories in the field of political sciences).

${ }^{16}$ David Easton, A Re-Assessment of the Concept of Political Support, 5 BRIT. J. POL. SCI. 435-57 (1975).
} 
now not possible to employ the good old Techniques de Coup d'État, ${ }^{17}$ where the military would take power or where the outgoing President refuse to leave. Populist parties arrive in power with a precise constitutional strategy, and they now play by the constitutional rules. They do not reject the idea of a constitution and they acknowledge its necessity to implement their rhetoric. Populist parties know the mechanisms of the constitutional system they evolve in and the weaknesses of the checks and balances. The analogy with parasite contamination illustrates this specificity of the populist strategy. Populism is an intra-consequence of constitutional democracy-it plays by its rules with the specific objective to destroy it, the same way a parasite eventually kills its host. With the populist strategy, consolidated democracies are no longer unbreakable democracies, as proven by the examples of Hungary and France.

\section{Viktor orban's strategy: A progressive deconstruction of the post-communist constitutional transition \\ I. The Fidesz constitutional corpus: The 2011 constitution, its amendments and the new legal system}

In 2010, Viktor Orban and Fidesz's political party not only won the general elections, but also arrived in power with the clear intention of disrupting the post-communist legacy, and they were prepared for it. Viktor Orban's strategy relied not only on winning the ballots. It was a combination of legal and constitutional reforms as the following table shows.

$$
\begin{aligned}
& 29 \text { May } 2010 \\
& \text { Nov. } 2010 \\
& \text { Jan. } 2011 \\
& 18 \text { April } 2011 \\
& 31 \text { Dec. } 2011 \\
& 1 \text { Jan. } 2012 \\
& 1 \text { Jan. } 2012 \\
& 11 \text { March } 2013 \\
& 23 \text { Dec. } 2013 \\
& 6 \text { June } 2014
\end{aligned}
$$

\author{
Fidesz's victory in the general elections \\ Amendment of Article 32 of the 1949 Constitution \\ New legislation on media \\ Assessment of the Fundamental Law \\ Act on the Transitional Provisions of the Fundamental Law \\ Commencement of the Fundamental Law \\ Act CCIII On the Elections of Members of Parliament of Hungary \\ Fourth Constitutional Amendment Act \\ Electoral Law Act \\ Fidesz's second victory in the general elections
}

The destruction of the post-communist legacy did not start with the adoption of the new Constitution in 2011. The so-called Fundamental Law was a constitutional revolution as it replaced the 1949 Constitution-it was key in Fidesz's strategy. As the table shows, Fidesz's strategy started as early as 2010 with three important acts: First, an amendment of Article 32 of the 1949 Constitution; second, a new legislation on media adopted in January 2011; and third, the Act on the Transitional Provisions of the Fundamental Law adopted in 31 December 2011, just before the commencement of the Fundamental Law. Moreover, Fidesz's strategy did not stop after the commencement of the 2011 Fundamental Law on 1 January 2012. On the same day, the Parliament adopted Act CCIII on the Elections of Members of Parliament of Hungary, almost a year after the Parliament amended the Fundamental Law with the Fourth Constitutional Amendment Act. Finally — six months before the 2014 general elections — the Parliament changed the electoral rule with the adoption of a new Electoral Law. The different texts adopted between 2010 and 2013 illustrate Viktor Orban's populist strategy: Getting the two-thirds majority at the

${ }^{17}$ Curzio Malaparte, Coup d’Etat: The Technique of Revolution (1932). 
Parliament, destroying political pluralism, muzzling the constitutional court and the media, and manipulating the results of the 2014 elections. $^{18}$

Article U(1) of the 2011 Fundamental Law reads:

The form of government based on the rule of law established in accordance with the will of the nation through the first free elections held in 1990 and the previous communist dictatorship are incompatible. The Hungarian Socialist Workers' Party, its legal predecessors, and the other political organizations established to serve them in the spirit of communist ideology were criminal organizations. [...] Political organization-having gained legal recognition during the democratic transition as legal successors of the Hungarian Socialist Workers' Party-continue to share the responsibility of their predecessors as beneficiaries of their unlawfully accumulated assets. ${ }^{19}$

The adoption of Article U(1) illustrates Fidesz's constitutional strategy when they took the power. Article $\mathrm{U}(1)$ was initially a provision of the Act on the Transitional Provisions of the Fundamental Law (The Transitional Act), adopted on 31 December 2011—one day before the commencement of the Fundamental Law. The Transitional Act remained a legal provision and became a constitutional provision (Article $\mathrm{U}(1)$ ) in March 2013 with the Fourth Constitutional Amendment Act.

Article U(1) of the 2011 Constitution is a historical fiction created to criminalize the Hungarian Socialist Party and to take it out of the Hungarian political game. With Article U(1), Fidesz transposed into the Constitution a fake representation of the post-communist democratic transition. Article $\mathrm{U}(1)$ created an incompatibility with the previous communist regime and the first government based on the rule of law. In other words, Article U(1) considers that the post-communist democratic transition was a clear-cut revolution where the true people- "the will of the Nation"stood up against and reversed the communist oppressor, the Hungarian Socialist Worker's Party. This vision of the Hungarian democratic transition is a historical manipulation. The Hungarian democratic transition was a negotiated transition. The communist regime was never reversed but, on the contrary, was the leading actor of the negotiations. ${ }^{20}$ The first free and fair elections mentioned in Article U(1) could only take place thanks to the willingness of the Hungarian Socialist Worker's Party to negotiate-and to secure its own future. ${ }^{21}$

The objective of Article U(1)'s historical fiction was not only to rewrite Hungarian constitutional history. The objective was also to condemn the Hungarian Worker's Party for the human rights violations committed during the communist period. To some extent, this condemnation echoed a certain logic of transitional justice. One can still question the efficiency of such a process twenty years after the end of the democratic transition. How, for example, do we evaluate the indebtedness of the country - the fourth type of accusation — and differentiate between the debts

\footnotetext{
${ }^{18}$ This Article deals only with the early waves of constitutional and legal reforms. They illustrate, in my opinion, the readiness of Fidesz party to change the Hungarian constitutional order. New attacks on democracy — such as the closure of Central European University - might appear more spontaneous or, at the least, part of a different strategy. The reader can find a thorough overview of the post-2014 reforms in Gábor Halmai, Populism, Authoritarianism and Constitutionalism, in this issue; and Kim Lane Scheppele, The Opportunism of Populists and the Defense of Constitutional Liberalism, in this issue.

${ }^{19}$ Article U(1), Hungary's Constitution of 2011 with Amendments Through 2016, CONSTITUTE ProjeCt, 12 (2016) [hereinafter Hungary's Constitution Through 2016].

${ }^{20}$ Andrew Arato, Post Sovereign Constitution Making: Learning And Legitimacy (2016).

${ }^{21}$ A negotiated transition — such as the Hungarian one - is driven by a four-player game, as the two camps of the transition are divided into hard-liners - those in the authoritarian camps who do not wish any democratic transition- and soft-linersthose who see in the negotiation as a way to pursue their interests. See Guillermo O’Donnell \& PhilipPe C. SCHMitTer, Transitions from Authoritarian Rule: Tentative Conclusions About Uncertain Democracies 17 (1986).
} 
contracted during and after the communist period ${ }^{22}$ The content of Article U(1) suggests that Fidesz wanted to look for a common enemy, a "non-people" as the populist rhetoric insinuates. In Fidesz's interpretation of democracy, everyone who was or who is still connected to the previous communist regime is not deemed to be part of the Nation.

The objective of Article U(1) was not only the creation of a fictional majority-it aimed at criminalizing the Hungarian Socialist Party, the main party of opposition, back in 2011. Article $\mathrm{U}(1)$ creates a connection between the former communist party and the now Hungarian Socialist Party. The connection between the two existed since the Hungarian Socialist Party succeeded the Hungarian Socialist Worker's Party just before the first free and fair elections in 1990. Institutionally speaking, the Hungarian Socialist Party was still a new party which came into being after the dissolution of its communist predecessor. Legally speaking, it is impossible to consider that the Hungarian Socialist Party should "share the responsibility of their predecessors as beneficiaries of their unlawfully accumulated assets." ${ }^{23}$ Politically speaking, the incrimination of the Hungarian Socialist Party contributed to the creation of an imaginary narrative-as well as allowing for the commencement of criminal actions-against a legitimate opponent of Fidesz.

Fidesz's attack against the Hungarian Socialist Party seemed to have been fruitful considering the result of the 2014 parliamentary elections. Fidesz obtained $66 \%$ of the seats, three times more than the $19 \%$ of the Hungarian Socialist Party. Hidden behind this veil of victory is a clever manipulation of the electoral results. In comparison with the 2010 elections, Fidesz's share of the popular votes dropped from 53\% to 45\%. The Hungarian Socialist Party's score grew from $19 \%$ to $25 \%$ despite the governmental propaganda. The gap between popular vote and number seats was the result of the new electoral law adopted on December 23, 2013. This law reinforced the leverage effect in decreasing the number of seats from 386 to 199 and increasing the threshold of representation. The electoral law increased the threshold from 5\% to $10 \%$ of the vote and $15 \%$ in case of coalition. Fidesz finally played with the electoral districts to ensure its victory in the majoritarian districts. ${ }^{24}$

\begin{tabular}{cccccc} 
& \multicolumn{2}{c}{ Fidesz } & & \multicolumn{2}{c}{ Socialist Party } \\
\cline { 2 - 3 } & Popular vote & Number of seats & & Popular vote & Number of seats \\
\hline 2010 Elections $^{25}$ & $53 \%$ & $263 / 386(68 \%)$ & & $19 \%$ & $59 / 386(15 \%)$ \\
2014 Elections $^{26}$ & $45 \%$ & $133 / 199(67 \%)$ & & $26 \%$ & $38 / 199(19 \%)$ \\
\hline
\end{tabular}

Fidesz coupled the attacks on political opposition with restrictions on the freedom of the media. Restrictions on the media did not take the form of classic and obvious authoritarian censorship. Fidesz diversified its strategy of legal modifications. In January 2011, under the older constitutional regime, Fidesz adopted new legislation aimed at the media. With this legislation,

\footnotetext{
${ }^{22}$ Indebtedness of the country is only one of nine types of accusations. Paragraphs 1-a to 1-I of Article U(1) include, among others: The betrayal of the Nation; the planned economy; the devastation of the traditional values of European civilization; the oppression of the 1956 Budapest uprising; etc.

${ }^{23}$ Hungary's Constitution Through 2016, supra note 17, https://www.constituteproject.org/constitution/Hungary_2016.pdf? lang=en.

${ }^{24}$ OSCE \& Venice COMm'N, Joint Opinion on the Act on the Elections of Members of Parliament of Hungary 8 (2012), https://www.osce.org/odihr/91534 ("[T]here is, however, a higher risk that a party winning a majority of seats in a singlemember constituencies gets a majority of seats in parliament even if the party is not the largest one nationwide.”). Gábor Halmai, in this issue, draws the same conclusion for the 2018 elections whilst acknowledging the growing support of the electorate for populist leaders.

${ }^{25} 2010$ Hungarian Parliamentary Election, WIKIPEDIA, https://en.wikipedia.org/w/index.php?title=2010_Hungarian_ parliamentary_election\&oldid=872453033 (last visited Jan. 15, 2019).

${ }^{26} 2014$ Hungarian Parliamentary Election, WIKIPEDIA, https://en.wikipedia.org/w/index.php?title=2014_Hungarian_ parliamentary_election\&oldid=872453044 (last visited Jan. 15, 2019).
} 
two newly created administrative institutions could limit any editorial content which would go against morality and public order. ${ }^{27}$ Using the excuse of morality and public order is a classic authoritarian strategy of censorship. Morality coupled with public order is a fantastic tool of oppression. The government can adapt its censorship to changing objectives and can progressively build up a constant climate of fear in the media.

The Fourth Constitutional Amendment Act, adopted in March 2013, is perhaps the most severely restrictive on political pluralism. The new version of Article IX.3 of the 2011 Fundamental Law restricts the use of media for political propaganda. ${ }^{28}$ It prohibits the use of political advertising in private media and limits political propaganda during electoral campaigns to public media coverage. Article IX.3 creates an unjustified gap between the party in powerwhich benefits from a massive media coverage-and the opposition parties-which are deprived of "an important chance to air their views effectively and thus to counterweigh the dominant position of the Government in the media coverage." 29 The history of Article IX.3 clearly illustrates Fidesz's constitutional and legal strategy. Originally, this restriction on political pluralism first appeared not in the Fundamental Law, but in the 2012 Act on Electoral Procedure. The thenindependent Constitutional Court stood against the government and annulled the discriminatory dispositions of the 2012 Act. With the adoption of the Fourth Constitutional Amendment Act, Fidesz incorporated the unconstitutional measure into the Constitution and bypassed the Court's decision.

A final point of Fidesz's constitutional strategy dealt with the Hungarian Constitutional Court, which positioned itself as the guardian of the democratic transition. The Court was already forced to accept the incorporation of the new media policy, but Fidesz's strategy went further and aimed to destroy twenty years of progressive jurisprudence. The muzzling of the Constitutional Court echoed the little respect Fidesz had shown for the rule of law. Fidesz did not only play the card of popular legitimacy against legal technocracy. Indeed, it did not stop at a rhetoric of the will of the majority against the decision of a non-elected technostructure. Fidesz coupled its populist rhetoric with a fine-tuned strategy of constitutional amendments. The destruction of the Court's legacy started as early as November 2010 with an amendment of the 1949 Constitution. ${ }^{30}$ The amendment modified article $32(\mathrm{~A})$ and limited the competency of the Court to specific areas. ${ }^{31}$ Before the amendment, article 32(A) did not foresee any limit to the Court's activity, which was essential for its progressive jurisprudence. ${ }^{32}$ After this amendment, article 32(A) became the Court's muzzle.

The adoption of the 2011 Fundamental Law led to an even greater censorship of the court. The Fundamental Law changed the nomination of the President from an inter pares nomination to an election by the National Assembly. ${ }^{33}$ It erased the Nomination Committee and required election of

\footnotetext{
${ }^{27}$ Philippe Boulanger, La Seconde Révolution Hongroise, 138 COMmentaire 401, 402 (2012).

${ }^{28}$ Hungary's Constitution Through 2016, supra note 17, https://www.constituteproject.org/constitution/Hungary_2016.pdf? lang=en ("During the electoral campaign period for the formation of democratic public opinion, political advertisements may be published only in media services free of charge, under conditions guaranteeing equal opportunities.").

${ }^{29}$ Venice COMM'N, Opinion on the Fourth Amendment to the Fundamental Law of Hungary, 95 ${ }^{\text {th }}$ Sess., II 45 (2013) https:// www.venice.coe.int/webforms/documents/?pdf=cdl-ad(2013)012-e.

${ }^{30}$ Venice Comm'N, Opinion on Three Legal Questions Arising in the Process of Drafting the New Constitution of Hungary, II 9 (2011) https://www.venice.coe.int/WebForms/documents/default.aspx?pdffile=CDL-AD(2011)001-e.

${ }^{31} I d$.

The Constitutional Court may assess the constitutionality of Acts related to the central budget central taxes stamp duties and contribution's, [...] exclusively in connection with the rights to life and human dignity, the protection of personal data, the freedom of thought, conscience and religion or with rights related to the Hungarian citizenship.

${ }^{32}$ Act XX of 1949 The Constitution of the Republic of Hungary, art. 32(a)(2) (1989), http://lapa.princeton.edu/hosteddocs/ hungary/1989-90\%20constitution_english.pdf (last visited Jan. 16, 2019) ("The Constitutional Court shall annul any laws and other statutes that it finds to be unconstitutional.").

${ }^{33}$ Hungary's Constitution Through 2016, supra note 17, arts. 1(2)(a), 24(8).
} 
judges directly by the National Assembly. It extended the number of the judges from eleven to fifteen. All these elements allowed the Fidesz party-which, since 2010, is majoritarian at the House-to recompose the Constitutional Court. Controlling the nomination of the constitutional judges was not enough. The preamble of the Fundamental Law as adopted in 2011 contained the premise of much larger censorship. The preamble proclaimed the invalidity of the "communist Constitution of 1949 , since it was the basis for tyrannical rule." ${ }^{34}$ Not only did the original Constitution of 1949 become invalid; so too were the series of 1989 constitutional amendments implementing the democratic transition and the jurisprudence of the Court interpreting this constitutional corpus. ${ }^{35}$ The 2013 Fourth Constitutional Amendment Act confirmed this strategy of censorship. The act limited constitutional review to the 2011 Fundamental Law. ${ }^{36}$ Every decision of the Hungarian Constitutional Court taken under the post-communist Constitution became ineffective, including its progressive jurisprudence on freedom of marriage, access to the media by political parties, freedom of expression, and even the death penalty. In four years-and after a fine-tuned constitutional strategy-the Constitutional Court moved from the guardian of the democratic transition to the guardian of Viktor Orban's revolution.

\section{The weaknesses of the post-communist constitutional system}

How could the Hungarian constitutional democracy be so easily disrupted? This was the same democracy which was often acknowledged as the most brilliant example of post-communist democratic transition, backed up by both a progressive Constitutional Court and a successful adhesion to the European Union.

To understand Fidesz's success, it is necessary to put the 2011 Constitution in a broader timeline and to come back to the post-communist democratic transition. I would like to demonstrate a continuity between the two constitutional transitions Hungary experienced since the fall of communism. The first constitutional transition started in 1989. It was not a revolution, but rather a negotiation between the former authoritarian rulers and a political opposition. This negotiated democratic transition led to a series of amendments of the 1949 Constitution and started the postcommunist constitutional system. The post-communist constitutional system lasted until the second constitutional transition. The second constitutional transition was the adoption of the 2011 Fundamental Law after the large victory of the Fidesz party in the 2010 parliamentary elections. Despite the thirty years which separates them-and the fundamental difference on the very notion of constitutional democracy - the two constitutional transitions are connected. The 2011 constitutional transition is, in my opinion, the denouement of the 1989 constitutional transition. I do not insinuate that the current state of democracy in Hungary is explained exclusively by a specific constitutional context. What I argue is that the post-communist constitutional system-despite tremendous changes in the protection of human rights and balance of powers-did not address basic constitutional and legal issues. Fidesz is a product of the democratic transition. It took part in the amendments of the 1949 Constitution and was perfectly aware of the system's deficiencies. Once in power - and with the support of a constitutional majority — the Fidesz party used the system's deficiencies to implement its populist rhetoric and eventually destroy Hungarian constitutional democracy.

\footnotetext{
${ }^{34} I d$., at preamble.

${ }^{35}$ VeNICE COMM'N, Opinion on the New Constitution of Hungary, III 35, 36 (2011) https://www.venice.coe.int/WebForms/ documents/default.aspx?pdffile=CDL-AD(2011)016-e.

${ }^{36}$ Hungary's Constitution Through 2016, supra note 17, art. 24.
} 
The main deficiency of the post-communist constitutional system was the lack of veto players in the constitutional amendment procedure. A veto player is defined as a collective or individual actor who must consent to a change of the status quo. ${ }^{37}$ In constitutional law, veto players refer to a number of actors such as the President, the Parliament, the citizenry, or the constitutional court involved in the constitutional amendment procedure. Veto players can intervene at different times in the amendment procedure. A Constitutional Court, for example, can not only intervene before the adoption amendment by controlling the substantial validity of the amendment but also later in the process by controlling the legality of the referendum adopting the amendment. ${ }^{38}$ Veto players are a constitutional drafting technique. Their incorporation does not guarantee an evolution of the constitution in a linear direction. The efficiency of the veto players also depends on a specific political and social context ${ }^{39}$ as well as a widespread constitutional culture. The absence of veto players has facilitated disruptive reforms - the less veto players there are, the easier it is for populist parties to disrupt constitutional democracy.

Veto players must intervene during the three phases of a constitutional amendment: The initiative, the adoption, and the control. Sharing the initiative between different actors can allow the tenure of a genuine social debate on the constitutional amendment. The best illustration is to give the initiative of the amendment to a share of the citizenry supported by a parliamentary majority. ${ }^{40}$ Without going as far as a popular activation of the amendment procedure, different institutions can share the initiative. Under the post-communist constitutional system, there was no distinction between the initiative of a constitutional amendment and the initiative of regular legislation. Article 25(1) of the 1949 Constitution shared the initiative of any legislative act between the President of the Republic, the Government, every commission of the National Assembly, and every deputy. Sharing the legislative initiative between different institutions might be a satisfactory veto player, but only if the said institutions represent different political interests. In Hungary, because of the parliamentary regime of the post-communist constitutional system, the executive and the legislative institutions belonged to the same political party. When Fidesz won the 2010 general elections, it automatically got the presidency and the government, in addition to the National Assembly. The initiative of the constitutional amendment procedure, in reality, emanated from the majoritarian political party and did not open any window for political debate.

Veto players engage in their most tremendous role during the adoption of a constitutional amendment. The usual veto player mechanism is the adoption of legislation by a qualified majority and in more than one institution-two Chambers of the Parliament, the population, the regions, etc. In Hungary, the National Assembly has been the only institution involved in the adoption of a constitutional amendment. Because of a compromise found during post-communist negotiations, the parliament was unicameral, ${ }^{41}$ which minimized considerably inter-institutional

\footnotetext{
${ }^{37}$ Bjørn Erik Rash, Foundations of Constitutional Stability: Veto Points, Qualified Majorities, and Agenda-Setting Rules in Amendment Procedures, ECPR JoInT SEssions of Workshops 8 (2008) https://ecpr.eu/Filestore/PaperProposal/d634bfdc6239-40a0-98b6-38b5fbba9f43.pdf.

${ }^{38}$ Constitutional amendment procedures, and the softness or rigidness of a constitution, can then be recorded in terms of veto points. In this example, two veto players — the constitutional court and the population — give three veto points. See Bjørn Erik Rash \& Roger D. Congleton, Amendment Procedure and Constitutional Stability 536, 546, http://www.rdc1.org/ forthcoming/DCD\%20(Chap\%2012,\%20Amendment\%20Procedures,\%20Congleton\%20and\%20Rausch).pdf.

${ }^{39}$ Andrew Roberts, The Politics of Constitutional Amendment in Post-Communist Europe, 20 Const. POL. ECON. 99, 114 (2009) ("It is less political institutions and constitutional procedures that drive amendments rates than contextual changes that occur with the passage of time.").

${ }^{40}$ Venice Comm'N, Report on Constitutional Amendment, If 33 n. 19 (2010), https://www.venice.coe.int/webforms/ documents/?pdf $=\mathrm{cdl}-\mathrm{ad}(2010) 001-\mathrm{e}$ (illustrating the example that the Serbian Constitution foresees a threshold of 150,000 voters for the initiative of the constitutional amendment).

${ }^{41}$ The communist rulers advocated for a strong President figure in order to negotiate with the presidency and to keep a strategic position of power. The political opposition argued, on a contrary, for a weak President and a strong parliamentary power, betting on a defeat of the communists during the next elections. See Jon Elster, Constitution Making in Eastern Europe:
} 
dialogue. Controlling the National Assembly was not sufficient to amend the constitution because the post-communist Constitution foresaw a qualified majority of two-thirds. It would be naive, however, to consider this two-thirds majority as an efficient veto player mechanism. The electoral law - another legacy of the democratic transition — made it easy for a party to obtain the qualified majority. ${ }^{42}$ The voting system was based on a regional representation split into majoritarian and proportional lists. ${ }^{43}$ Theoretically, proportional representation facilitates a pluralistic representation in the Parliament. ${ }^{44}$ Proportional representation should complicate the formation of a politically qualified majority, or at least require the dominant political party to negotiate and compromise with other political forces. But political pluralism depends on the threshold of representation needed to enter the Parliament. In the Hungarian Constitution, even though this threshold was low-4\% in 1990 and 5\% in 2010 - only four political parties managed to get the number of votes necessary to enter the Parliament during the 2010 elections. Pluralism was also badly affected by a strong leverage effect due to the majoritarian facet of the voting system. Therefore, while representing only $52 \%$ of the votes, Viktor Orban's party obtained $68 \%$ of the seats and the qualified majority was required to adopt a new constitution. ${ }^{45}$

Veto players can intervene to control a constitutional amendment-most of the time through the constitutional review of the Constitutional Court. In such a case, the procedure differs from ordinary constitutional review. When a Constitutional Court assesses the constitutionality of a piece of legislation, the control is both formal and substantial. In the case of a control of a constitutional amendment, a substantial control is less likely to happen in order to preserve the balance between majoritarian and rule of law pillars. It is indeed assumed that the adoption of a constitutional amendment is an expression of the constituent power and not simply a decision of the constituted power. If a Constitutional Court is competent to control a constitutional amendment, the control would often be formal and limited to checking the regularity of the procedures. In Hungary, the post-communist Constitution did not distinguish between constitutional and ordinary laws. In other words, the Constitutional Court could have theoretically been competent to control the constitutionality of the 2011 constitution. The problem was not the capacity of the Court to intervene or even decide on its legitimacy. The Court, because of its progressive jurisprudence, was legitimate-perhaps the most legitimate institution to decide on the future of the country. ${ }^{46}$ The issue during the adoption of the 2011 Fundamental Law was rather that the recourse to the Constitutional Court was optional and depended on the willingness of the President of the Republic. Since the then-President of the Republic, Pál Schmitt, had been appointed by Fidesz, he did have recourse the Court. The Constitutional Court-despite its

Rebuilding the Boat in the Open Sea, 71 PuB. ADMIN. 169, 190 (1993); see also Lajos Lorincz, Réforme Constitutionnelle et Administrative en Hongrie, 23 Revue d'Études Comparatives Est Ouest 49, 51 (1992).

${ }^{42}$ This voting system was also a result of the negotiations during the democratic transition. A majoritarian representation was supported by the communists - who wanted to personify the election in order to minimize the negative impact of the communist legacy. The opposition, conversely, wanted a proportional representation in order to increase political pluralism and to decrease the influence of the communist party. See Ethan J. Hollander, Democratic Transition and Electoral Choice: The Legacy of One-Party Rule in Hungary and Poland, 16 J. IND. ACAD. Soc. SCI., 88, 95-99 (2013).

${ }^{43}$ Antal Visegrády, Transition to Democracy in Central and Eastern Europe: Experiences of a Model Country-Hungary, 1 WM. \& MARY BILL RTS. J. 245, 248 (1992) https://pdfs.semanticscholar.org/4984/43533064d73096cec04d7d8e946939f6d13e. pdf.

${ }^{44}$ Report on Constitutional Amendment, supra note 38, at II 22.

${ }^{45} 2010$ Hungarian Parliamentary Election, supra note 23.

${ }^{46}$ See László Sólyom \& Georg Brunner, Constitutional Judiciary in a New Democracy: The Hungarian Constitutional Court (2000) (presenting an overview of the landmark decisions); see also László Sólyom, The Role of Constitutional Courts in the Transition to Democracy: With Special Reference to Hungary, 18 INT'L Soc. 133 (2003) (presenting a more analytical study on this subject); Gábor Halmai, The Hungarian Approach to Constitutional Review: The End of Activism? The First Decade of the Hungarian Constitutional Court, in Wojciech Sadurski (ed), ConstiTUTIONAL JUSTICE, EAST AND WEST: DEMOCRATIC LEGITIMACY AND CONSTITUTIONAL COURTS IN POST-COMMUNIST EUROPE IN A COMPARATIVE PERSPECTIVE (Kluwer Law International 2003). 
essential role in the consolidation of the democratic transition-did not have a word to say on the constitutional amendment because the activation of the control was left to the discretion of one institution.

The post-communist Hungarian Constitution was key in supporting a democratization process for more than twenty years. Nevertheless, the overall constitutional architecture did not match the standards which could have guaranteed minimal protection against democratic backslidings. Ironically, the 1995 Constitution, which was never adopted, corrected a lot of these flaws. ${ }^{47}$ Viktor Orban and the Fidesz party were fully aware of these weaknesses - the adoption of the 2011 constitution must not be seen as a spur-of-the-moment phenomenon. The Hungarian saga illustrates well the constitutional strategy behind the veil of populist rhetoric.

\section{Marine Le Pen's strategy: A comprehensive constitutional amendment by referendum}

\section{The content of Marine Le Pen's constitutional program}

During the 2017 presidential campaign, Marine le Pen published two programs: A presidential program with her traditional anti-immigration rhetoric, and a twelve-page constitutional program, named the "constitutional reform that I propose to the French people by referendum." 48 Whereas the former document provoked waves of comments from the commentators and political specialists, the latter document remained under the surface of political debates. Reactions and analysis focused on the triptych of security, immigration, and unemployment. Paradoxically enough, in a consolidated democracy such as the French one, the objectives of a constitution do not go hand in hand with the interests of politicians and commentators. Projections and longterm visions of the institutions - the main attributes of a constitution-clash with the short-term actions and the immediate communications of politics. No one really took to the measure of the revolution undertaken by FN. This was a revolution in method-as it was the first time that FN ever detailed its agenda of institutional reforms - but also it a revolution through the impact of the reforms. Marine le Pen's ambition did not stop at leaving the EU-she aimed to transform the organization of the French State and its constitutional and institutional balance, and to eventually strike down the French État de droit.

Marine le Pen's strategy differed from Viktor Orban's progressive deconstruction of the postcommunist legacy. FN's institutional reforms consisted of a constitutional amendment package that would have been proposed by referendum within the first months of the mandate. The objective of the constitutional amendments was to restore the "greatness of the constitution" thanks to a reinforcement of its democratic attributes. ${ }^{49}$ In reality, Marine le Pen's constitutional program is nothing less than a transposition of FN's populist rhetoric to three domains: The constitutional principles, the political institutions, and the referendum.

Nationalism and xenophobia were, are, and will remain the essence of FN's political identity. Since her arrival at the head of the party in 2011, Marine le Pen has tried to get rid of this image by putting on the mask of populism, but the first two points of the constitutional program-the constitutional principles and the political institutions-are a gentle reminder of what FN truly is. The first point of the program foresees the inscription of new fundamental constitutional

\footnotetext{
${ }^{47} \mathrm{~A}$ specific recommendation of the Venise Commission foresees concrete measures to increase constitutional rigidity and to avoid the situation where the "governmental majority [is] the same as the constitutional power ...." See VENICE COMM'N, Opinion on the Regulatory Concept of the Constitution of the Hungarian Republic, $\$ 17$ (1995), https://www.venice.coe.int/ webforms/documents/?pdf=CDL(1995)073rev-e; see also Martyn Rady, The 1994 Hungarian General Election, http://www. tandfonline.com/doi/abs/10.1080/00344899438439053 (last visited Oct. 6, 2016).

${ }^{48}$ La Révision Constitutionelle que Je Propose aux Français par Référendum, (last visited Nov. 10, 2017), https://en.calameo. com/read/0007841419d18a563b624.

${ }^{49} I d$. at 2 ("I do not intend to overturn the French equilibrium of powers, but I intend to come back to the original spirit of our Constitution, by considerably strengthening its democratic attribute.”).
} 
principles, namely the "defense of our identity as a people," the "national priority," and the "fight against communitarianism." The three principles echo FN's populist rhetoric and FN's vision of majority. "Our identity as a people" is FN's unified and Unitarian majority-French but preferably white and Christian. "National priority" and the "fight against communitarianism" are FN's tyranny of the minority-they claim that multiculturalism and immigration destroyed French national unity. FN's fictional majority and tyrannical minority are a negation of French history. Over the last century, France was built thanks to immigration - on the diversity of peoples and not on a mythological vision of one timeless people. FN's new constitutional principles are a negation of French constitutional culture which, as Article 1 of the constitution states, is grounded on an "equality of all citizens before the law without distinction of origin, race or religion (and a respect of) all beliefs." 50

The second point of the constitutional program-the political institutions-illustrates the tyranny of the minorities which can only be, in FN's vision, a consequence of European integration. The best way to fight European oppression is a shield of nationalism and a deconstruction of the European national framework. Marine le Pen aimed at "restor(ing) the superiority of national law," 1 thanks to a deletion of Title XV of the Constitution which organizes the relations between the French State and the EU institutions. Marine le Pen's nationalism seems to avoid the complexity of reform in a legal system where the majority of national laws are a transposition of EU legislation. Here, Marine le Pen's ambition is a "Frexit" in all but name. The second point of the constitutional program went beyond European integration and included all form of supranational cooperation. It foresaw a repeal of Article 55 of the Constitution in order to re-establish the authority of national laws over international treaties, as well as the superiority of national judicial institutions over supra-state courts. ${ }^{52}$

Nationalism and xenophobia should come as no surprise in the study of any of FN's programs, but institutional transformations did represent a new step in FN's strategy. In this constitutional program, there was a willingness to go beyond ideology and to disrupt the constitutional equilibrium of the French semi-presidential system. Disruption is not a hyperbolic term to characterize FN's reforms. FN's “voice of the Nation” is a non-representative and a non-plural voice. FN's national organization relies on a strong figure-Marine le Pen-on a monarchical vision of power - the father, the daughter, and the grand-daughter-and on a hyper-centralized territorial organization. Marine le Pen wanted to transpose this authoritarian practice of party power to the French institutional model - the constitutional program would have bolstered the powers of the President of the Republic to the detriment of the legislative counter-power.

Originally, the French semi-presidential system gave room for political compromise. The peculiarities of the semi-presidential system are not the duality between the head of State-the President of the Republic - and the head of government - the Prime Minister. Rather, what distinguishes this atypical form of government from the others is the election of the President of the Republic via universal and direct suffrage. ${ }^{53}$ The popular input legitimacy of the President of the Republic is then much stronger than that of the Prime Minister, who is appointed by the President of the Republic on the basis of the political majority of the National Assembly. Political compromises emerged in the so-called periods of cohabitation when-because of different electoral timing - the political majority of the presidential election differed from the political majority of

\footnotetext{
${ }^{50}$ France's Constitution of 1958 with Amendments through 2008, CONSTITUTEPROJECT.org, art. 1 (2013), [hereinafter France's Constitution through 2008], https://www.constituteproject.org/constitution/France_2008.pdf?lang=en.

${ }^{51}$ La Révision Constitutionnelle, supra note 46 , at 4.

${ }^{52}$ Article 55 is not included in Title XV of the Constitution because of its general scope of application. See, e.g., id., art. 55 ("Treaties or agreements duly ratified or approved shall, upon publication, prevail over Acts of Parliament, subject [ ... ] to its application by the other party.").

${ }^{53}$ The President was not originally elected via direct suffrage - the electoral system changed in 1962 after a constitutional amendment. See Id., art. 6.
} 
the parliamentary election. In the case of a cohabitation, the President of the Republic had to rule with a Prime Minister from a different political party and was then forced to compromise. ${ }^{54}$ The balance of power changed drastically with the constitutional reform adopted in 2000. The aim of this reform was to erase any possibility of cohabitation by reducing the presidential mandate to five years and aligning the presidential elections with the parliamentary ones. ${ }^{55}$

This reminder is essential to see where FN stands-and to what extent its constitutional program was a misinterpretation of political reality. In the concluding remark of her constitutional program, Marine le Pen affirmed that "because of the five-year term, the President has found himself weakened." This affirmation is fallacious. With the five-year term, the President of the Republic has now more than ever become the key institution of the French institutional system. He has the insurance of governing for five years without parliamentary opposition. Since 2000, he has been both the head of State and, unofficially, the head of government. Marine le Pen's solution is to again change the presidential mandate into a non-renewable seven-year term. ${ }^{56}$ This solution is, at first sight, ambivalent. A seven-year term would reopen the doors for cohabitation and would put the President back in the position of compromise, as was the case before 2000. In reality, Marine le Pen followed a strategy of communicating vessels-increasing the powers of the President by decreasing the legitimacy of the National Assembly.

The strategy to decrease the legitimacy of the National Assembly is twofold. On the one hand, the constitutional program proposed a reduction by half of the total number of members of parliament-from 577 to 300 for the National Assembly and from 348 to 200 for the Senate. Such a reform would increase numerical representativeness-one member of Parliament would represent a larger chunk of the citizenry. Substantially though, reducing the number of representatives would decrease the quality of the representativeness and the legitimacy of the legislative power.

On the other hand, the constitutional program foresees the establishment of full proportional representation for all elections, starting with the legislative elections. In theory, proportional representation does allow for a more democratic representation, as every political party has a number of seats in parliament which corresponds to the number of votes it obtained. Proportional representation has long been part of FN's political agenda, which denounced the gap between the number of seats and the number of votes. ${ }^{57} \mathrm{FN}$ 's vision of proportional representation went in the exact direction of better representativeness. First, the constitutional program foresaw a $5 \%$ threshold for the entry of a political party into the National Assembly. A 5\% threshold remains a high threshold in comparison with the current electoral rules, and it would prevent important political forces from getting into the National Assembly. ${ }^{58}$ Second, FN wanted to set up a so-called "majority prime" of $30 \%$ of the seats for the winner of the legislative elections. The exact consequence of this majority prime remained unclear. Either the prime would add up to the percentage of the votes, or-and this is my interpretation-regardless of its score, the winner would be allocated a maximum of $30 \%$ of the seats. Hence, even a political party with a large majority of votes

\footnotetext{
${ }^{54}$ Three cohabitations took place before the 2002 constitutional amendment: François Mitterand and Jacques Chirac (1986-1988); François Mitterand and Édouard Balladur (1993-1995); and Jacques Chirac and Lionel Jospin (1997-2002).

${ }^{55}$ Loi Constitutionnelle 2000-964 du 2 Octobre 2000 Constitutionnelle Relative à la Durée du Mandat du Président de la République [Constitutional Law 2000-964 of October 2, 2000 on the Term of Office of the President of the Republic], JourNAL Officiel de la Republique Française [J.O.] [Official Gazette of France], Oct. 2, 20

${ }^{56}$ La Révision Constitutionelle, supra note 46 , at 10.

${ }^{57}$ The two-round voting system favors traditional parties — prioritizing the President's party — and leads to the formation of an anti-FN front. For example, in the last elections, FN obtained $13 \%$ of the votes but only 8 seats. In comparison, the conservatives obtained $21 \%$ of the votes and 136 seats, and the socialists obtained $7.5 \%$ of the votes for 30 seats. See Elections Législatives Françaises de 2017, WIKIPÉDIA, https://fr.wikipedia.org/w/index.php?title=\%C3\%89lections_1\%C3\%A9gislatives_fran \%C3\%A7aises_de_2017\&oldid=154745793 (last visited Dec. 17, 2018).

${ }^{58}$ For example, during the last legislative elections, the Communist Party obtained ten seats at the National Assembly with only $2 \%$. If one can denounce the gap between the seats and the actual size of the political party, the two-round majoritarian system allows small parties to get seats in areas where they are majoritarian.
} 
would have to form a political coalition to get a simple majority and to pass laws. And because of the semi-presidential system, the same compromise would have to be sought to form the government. The latter would see a decrease in its capacity to rule as well as a decrease in its political and popular legitimacy. ${ }^{59}$ The constant quest for a coalition goes against the French equilibrium. It significantly decreases the legislative power vested within the President. Arguing for better representativeness, Marine le Pen actually seeks to diminish the influence of the legislative power and eventually the influence of the government.

The constitutional program went on and foresaw the creation of a direct relation between the citizenry and the President. In order to "give the floor back to the people," Marine le Pen intended to normalize the use of the referendum. ${ }^{60}$ The use of the referendum is framed by articles 11(1), 11(3), and 89 of the 1958 Constitution. To activate Article 11(3) - the so-called popular initiative-Marine le Pen wanted to decrease the threshold from one tenth of the electoratearound 4.46 million - to 500,000 electors. ${ }^{61} \mathrm{FN}$ also wanted to extend the scope of the referendum to all the areas currently covered by the law-in negation of Article 34 of the Constitution which mandates the domains of competence of the Parliament. ${ }^{62}$ This strategy creates a parallel legislative process and bypasses the parliamentary work to the benefit of a much faster-and in appearance more democratic - referendum method. Any positive referendum on any public domain would be automatically translated into a law. Legislative processes would no longer be the monopoly of the Parliament. This reform would install a direct relation between the President and the citizenry at the expense of national representation and parliamentary debate.

The direct relation did not concern only the legislative arena. The constitutional program included a suppression of Article 89 of the Constitution, including the current procedure of constitutional amendment. With its constitutional program, FN wanted to impose a referendum not only for ordinary legislation, but also for constitutional amendments. Referendums sound attractive as they seem to put the Constitution back in the hands of the citizenry. Marine le Pen's vision of the reform is not democratic; it is just a way of circumventing the counter-majoritarian instruments of a constitutional democracy. French citizens would not participate in the democratic life-they would just be temporarily consulted, and perhaps manipulated, to approve choices of the President. Marine le Pen's constitutional program echoes a well-known practice in authoritarian regimes, where using the referendum justifies authoritarian backsliding and unconstitutional amendments. With such a practice anchored in the French Constitution, no constitutional disposition would be safe from authoritarian tendencies. Amending the Constitution through referendum could allow Marine le Pen to propose constitutional reforms which go beyond her original constitutional program, such as: The reestablishment of the death penalty; ${ }^{63}$ the modification of the electoral system if the National Assembly is too troublesome; or even the extension of the presidential mandate beyond the constitutional term.

This vision is in line with the populist rhetoric that believes rules cannot limit the majority and the right to amend the Constitution cannot be constrained by a specific constitutional amendment

\footnotetext{
${ }^{59}$ See Le Vote de Fonfiance au Gouvernement Valls II, L'EXPREsS (2014), https://www.lexpress.fr/actualite/politique/le-votede-confiance-au-gouvernement-valls-ii_1575709.html (last visited Nov. 12, 2017) (during the preceding governmental term, an internal scission of the socialist party resulted in several ministry crises which decreased the legitimacy of the Prime minister and the government).

${ }^{60}$ La Révision Constitutionnelle, supra note 46 , at 6.

${ }^{61} I$ d.

${ }^{62}$ France's Constitution through 2008, supra note 48 (precisely stating the domain of the law in Article 34 of the Constitution).

${ }^{63}$ During the campaign, Marine le Pen said that the reestablishment of the death penalty should be decided by referendum despite the fact that the Constitution explicitly states in Article 66-1, that "no one can be sentenced to death penalty". See FN: Marine le Pen Retire la Peine de Mort de son Projet Mais . ., LE PARISIEN (Feb. 2, 2017), -http://www.leparisien.fr/elections/ presidentielle/fn-marine-le-pen-retire-la-peine-de-mort-de-son-projet-mais-01-02-2017-6646128.php (last visited Nov. 13, 2017).
} 
majority. The Constitution shall be at the disposal of the population and-above all-of the President of the Republic, the one and only true representative of the Nation. Marine le Pen's constitutional program was not chimeric - it was a well-tuned constitutional strategy.

\section{The constitutional weaknesses of the French constitutional democracy}

Marine le Pen's defeat in the second round of the 2017 presidential elections might provide fuel to those convinced of the glass ceiling in the French political domain. FN cannot win a general election as its constitutional program will remain hypothetical—French institutions are and will be safe. The assumption is comforting, but it does not address the elephant in the room-if FN were to be elected, would the French institutions have been sufficiently solid to resist its assaults? By hiding themselves behind the glass ceiling theory, observers refuse to test if the French constitutional democracy is a proper consolidated democracy. This exercise appears essential after a closer look at Marine le Pen's strategy to implement her constitutional program.

Article 89 is the main constitutional amendment procedure of the 1958 Constitution. The initiative for constitutional amendment is shared between the President of the Republic, the Prime Minister's recommendation, and the members of Parliament-specifically the Senate and National Assembly. Article 89 gives two options for the adoption of the amendment. The first possibility for adoption is the adoption of the amendment, in identical terms, by a simple majority in the two Houses. ${ }^{64}$ In this case, the amendment takes effect only after approval of the text by referendum. The second possibility is the adoption by a three-fifths majority of a joint-sitting Congress. In this case, the amendment is directly adopted and the convocation of a referendum is not necessary. ${ }^{65}$ With the procedure of Article 89, the use of the referendum is only marginal and has barely been used by the executive power, which prefers the more secure convocation of the Congress.

At first sight, Marine le Pen's strategy to adopt her constitutional program via referendum seems naïve. Her wish to call for a referendum may match with her apparent willingness to give the floor back to the people. But if she were to follow the procedure of Article 89-and eventually aim to organize the referendum - then she would have to secure a majority in the two Houses first. Considering the political logic behind the elections of the National Assembly and the Senate, a FN majority in the two houses is not likely to happen-or, at least would not have been likely to happen even in the case of FN's victory at the general elections. In any case, asking the Houses was not in FN's plan, as Marine le Pen intended to adopt the constitutional program not by using Article 89 of the Constitution, but by via direct referendum, which seems ostensibly not constitutional.

Would the adoption of FN's constitutional program necessarily have ended in an unconstitutional amendment under a reform in violation of the constitutional amendment procedures? Did Marine le Pen drift into her strategy through ignorance of the constitutional reality? One should not underestimate FN's knowledge of the weaknesses of the French constitutional system.

The 1958 Constitution does mention direct referendum in Article 11, except for the case of a constitutional amendment. Article 11 foresees two possibilities for a direct referendum. A referendum can be initiated either by the President of the Republic via article 11(1) or, since 2008, by one-fifth of the members of Parliament representing one-tenth of the voters enrolled on the electoral lists via Article 11(3). In any case, the object of the direct referendum is restricted

\footnotetext{
64“A Government or a Private Member's Bill to amend the Constitution must be considered within the time limits set down in the third paragraph of article 42 and be passed by the two Houses in identical terms. The amendment shall take effect after approval by referendum", France's Constitution through 2008, supra note 48.

${ }^{65}$ However, a Government Bill to amend the Constitution shall not be submitted to referendum where the President of the Republic decides to submit it to Parliament convened in Congress; the Government Bill to amend the Constitution shall then be approved only if it is passed by a three-fifths majority of the votes cast. Id.
} 
to a government bill and is limited to six domains. ${ }^{66}$ As a direct referendum cannot be held on a constitutional amendment, Marine le Pen's constitutional strategy seems unconstitutional. If the text of the 1958 Constitution might go against FN's strategy, such is not the case with the constitutional practice. The use of Article 11(1) - a direct referendum invoked by the President- to amend the 1958 Constitution was an option taken by Charles de Gaulle in 1962. Charles De Gaulle wanted to amend the Constitution in order to install a direct election of the President. Because of the composition of the Parliament, he was uncertain that going through Article 89 would ensure him an adoption of the constitutional amendment. He decided to bypass the procedure he himself created four years earlier and instead extended the scope of Article 11(1) to the adoption of the constitutional amendment. This constitutional twist was obviously a violation of the 1958 Constitution - and it was on this basis that 60 members of the Parliament addressed the Constitutional Council. The Council—which was then lacking any institutional legitimacyrefused to invalidate the referendum on the pretext that it was a "direct expression of national sovereignty." 67

Since this decision, there has been a consensus among the institutions and within the constitutional doctrine that the President of the Republic can amend the Constitution through popular referendum without any control of the Constitutional Council. This constitutional practice has even been transformed into positive law with the adoption of the Institutional Act of $6^{\text {th }}$ December 2013 which specifies the role of the Constitutional Council in the application of Article 11 of the constitution. This organic law explicitly excludes the possibility of any judicial review of a constitutional amendment adopted based on Article 11(1) of the Constitution. ${ }^{68}$ Marine le Pen can justify her strategy by putting forward this constitutional precedent - and there is no legal ground to contest the constitutionality of her strategy.

Marine le Pen's strategy illustrates a deep knowledge of the peculiarities of the French constitutional system. In France, constitutional democracy is still safe because populism remains in opposition-but the elections should have been an early warning to reflect upon these constitutional weaknesses. There is, however, a widespread skepticism among scholars and political leaders towards conducting any form of self-reflection.

\section{E. Conclusion}

Understanding populist rhetoric is the key to understanding the relation between populism and constitutional democracy. It highlights the central place of the manipulation of the rule of law and the majoritarian pillars in the populist strategy. The rhetoric also offers an analytical frame for studying the transition from populism of opposition to populism of government. The fiction created by the rhetoric is essential to win elections, but the rhetoric itself contains germs for the postelection phase. When populism is in power, it comes prepared and ready to destroy constitutional democracy thanks to its precise constitutional strategy.

Part of the constitutional strategy is a commitment to reforms which threaten democracy or oppress minority rights by relying on and furthering a vision of the majority as the sole legitimate ruling entity. These reforms do not yet take place in an unconstitutional setting and this is where the complexity - or as some would say, the paradox-of populism appears. While on the one hand populist rhetoric rejects any sort of rule of law, populists, on the other hand, once in power,

\footnotetext{
${ }^{66}$ Namely: The organization of the public authorities; reforms relating to the economic, social, or environmental policy of the Nation and to the public services contributing thereto; and the authorization to ratify a treaty, which-although not contrary to the Constitution-would affect the functioning of the institutions. See France's Constitution through 2008, supra note 48.

${ }^{67}$ Conseil Constitutionnel [CC] [Constitutional Court] decision No. 62-20DC, Nov. 6, 1962, https://www.conseilconstitutionnel.fr/decision/1962/6220DC.htm.

${ }^{68}$ Loi Organique 2013-1114 du 6 Décembre 2013 portant application de l'article 11 de la Constitution [Organic Law 20131114 of December 6, 2013 implementing article 11 of the Constitution], Journal OfFiciel DE LA RePUbliQue FrançAISE [J.O.] [OfFicial GaZette of France], Dec. 6, 2013, art. 1.
} 
still rely on constitutional rules to implement reforms which threaten the rule of law. To some extent, this is how constitutionalism and populism could be reconciled. If a procedural vision of constitutional democracy is adopted, then populist constitutionalism is not an oxymoron. Both Marine le Pen's and Viktor Orban's strategies showed a clear intention to implement their populist rhetoric while respecting the constitutional order. The election of a populist party does not mean that the entire constitutional structure-with the check and balances, the veto players, and the human rights framework-will be negated. ${ }^{69}$ The process is slower and more vicious because populist play by the rules to gradually change the rules altogether. Populist constitutionalism is, however, limited to a procedural vision of democracy. Constitutionalism is above all a matter of democratic values, such as political pluralism, transnational solidarity, and protection of minorities. These values render constitutional democracy incompatible with populism. The ultimate goal of populism is the destruction of constitutional democracy, the negation of its spirit, and the perpetuation of the power of populists.

The contamination is subtle and malicious, but it is not cureless. The populist parasite will never disappear from constitutional democracy because populism is inherent to the features of constitutional democracy. The effects of its contamination can be limited, however, if we as scholars stand up and rise against the populist rhetoric. The spread of populism sped up-and so did the responding academic works. Academia must remain the central interpreter of the populist growth. Even if the trend during the last few years has been to multiply the number of studies - and perhaps sometimes to rush to conclusions - academia remains the last circle where a phenomenon such as populism can be studied, understood, and eventually defeated by virtue of long-term solutions.

The first solution is technical. The examples of France and Hungary show that constitutional tests of resilience could help identify constitutional weaknesses in a consolidated democracy. But the fight against populism is not simply a normative one. This is where the second solution comes into play, one which is sociological in nature. Scholars must acknowledge that the virtue of a constitutional democracy is evident for the academic community, but not for the majority of our compatriots. Citizens must become aware of what democracy truly is-not the will of the majority but a delicate equilibrium between the rule of the majority and the rule of law. How to use existing institutions to spread a wide constitutional culture among the citizenry is an issue constitutional lawyers should address urgently.

In this necessary work, I would like to propose an alternative-namely, to stop referring to Orban, Le Pen, and others as populists. Let us call them by what they really are. Populism has become a shield — and a dangerously accommodating one. Call Orban and Le Pen populists, their answer will be the same- "so what? Is there anything wrong in acting in the name of the people and making policies for the people"? Populism was meant to be a common label to stamp political actors on the wall of shame. The same actors used this wall to hide and protect themselves. Academia needs to deconstruct this wall, stone after stone, in order to reveal the real nature of populism-to identify what populists are protecting themselves from and to find what they are hiding. Academia must analyze populism in its "evil" diversity and realize that fascism-under Salvini-racism and antisemitism—under Le Pen—and nepotism—under Orban—are all different faces of the same populist mask.

\footnotetext{
${ }^{69}$ As Mark Tushnet explains in this issue, veto points work against populism in power, see Mark Tushnet, Varieties of Populism, in this issue.
}

Cite this article: Fournier T (2019). From rhetoric to action, a constitutional analysis of populism. German Law Journal 20 , 362-381. https://doi.org/10.1017/glj.2019.22 